\title{
Using computer simulation in the analysis of energy saving in green building; a case study
}

\author{
Omar Hujran*, Ghani Albaali \\ Princess Sumaya University for Technology, Amman 11953, Jordan
}

\begin{abstract}
The implementation of solar panels for a green building in Jordan to generate solar energy and to support the electricity supplied by the national grid is presented in this study. The photovoltaic panels used generate approximately $7.2 \mathrm{~kW}$ of electrical power, which is used for office lighting. RETScreen software and computer simulation is used for the analysis of renewable energy technologies. The Energy Model worksheet is used to evaluate the proposed case system, which is the photovoltaic one. The result showed that the project cash flow is positive. The annual energy saving is found of $9315.61 \mathrm{kWh}$, which will annually eliminate $920.7 \mathrm{tCO}_{2}$ of GHG. These findings support strongly the implementation of a local residential photovoltaic small project in Jordan, taking into consideration the escalating oil and natural gas price, and the decrease in photovoltaic technology cost.
\end{abstract}

Keywords: Green building, energy model, RETScreen software

\section{Introduction}

Photovoltaic (PV) technology is proven and easy to use solar energy to generate electricity. The PV sector is projected to continue to grow, in part due to feed in tariff support as well, due to grid parity economics in much countries.Another aspect is the necessity to deliver environmentally sound and sustainable solutions to the built environment. The global climate change and energy crisis demands lead to the approach of this work, which is studying the way buildings are designed, constructed and operated in order to reduce their impact on the natural environment.

The choice of the building has been the Embassy of the Netherlands as it integrates many "green building" technologies and it is the first building in Jordan to receive the prestigious international LEED (Leadership in Energy and Environmental Design) certification for green building, which is rated from the US Green Building Council (USGBC). RETScreen software has been used for the analysis of the renewable energy technologies, and the aspect subject to the analysis is the proposed case power system.The Energy Model worksheet is used to evaluate the proposed case system, which is the photovoltaic one.

\section{Energy Consumption and Electricity Outlook}

Around 1.5 billion people or more than a fifth of the world's population mostly in rural areas of developing countries have no access to electricity and further 2 billion are severely undersupplied [1].Of the people without electricity, $85 \%$ live in rural areas or on the fringes of cities. Total global energy use exceeds 102 Trillion $\mathrm{kWh}$ per year, which is equivalent to over 170 million barrels of oil each day [2]. Global energy consumption draws from six primary sources: $44 \%$ petroleum, $26 \%$ natural gas, $25 \%$ coal, $2.4 \%$ hydroelectric power, $2.2 \%$ nuclear power, and $0.2 \%$ non-hydro renewable energy. As the prices of oil and gas have been rising since the past decade, as well as, the awareness of the environmental impact of fossil fuels, the importance of renewable energy as a source of power has become more prominent [3]. On the global scale, renewable energy made up to $20.1 \%$ of electricity production, up by $1.4 \%$ from 2010 's energy mix. In terms of direct consumption of renewable energy, this stood at $12.7 \%$ of the global

\footnotetext{
* Manuscript received January 2, 2018; revised April 12, 2018.

Corresponding author. E-mail address: o.hujran@psut.edu.jo

doi: 10.12720 /sgce.7.2.152-158
} 
energy mix in 2011 [4].

The energy in Jordan is heavily dependent on imported crude oil and oil products to cover the energy needs. Energy imports account for nearly $10 \%$ of Growth Domestic Product GDP. According to international classifications, Jordan is one of the "sun-belt countries" with average daily solar radiation of $4 \mathrm{kWh} / \mathrm{m}^{2}$ in winter and more than $8 \mathrm{kWh} / \mathrm{m}^{2}$ in summer. This is why the solar energy is mainly used for domestic solar water heating for about $30 \%$ of residential units in the country [5]. The annual primary energy consumption (1000 toe) during 1997-2004 in Jordan is shown in Table (1).

Table 1. Annual primary energy consumption (1000 toe), during 1997-2004 in Jordan [6]

\begin{tabular}{|c|c|c|c|c|c|}
\hline \multirow[b]{2}{*}{ Year } & \multicolumn{4}{|c|}{ Primary Energy Type } & \multirow[b]{2}{*}{ Total } \\
\hline & $\begin{array}{l}\text { Crude Oil and Oil } \\
\text { Products }\end{array}$ & $\begin{array}{l}\text { Natural Gas in } \\
\text { billion } \mathrm{ft}^{3}\end{array}$ & $\begin{array}{c}\text { Renewable } \\
\text { Energy }\end{array}$ & $\begin{array}{l}\text { Imported } \\
\text { Electricity }\end{array}$ & \\
\hline 1997 & 4385 & 10.7 & 65 & & 4673 \\
\hline 1998 & 4491 & 10.9 & 67 & & 4784 \\
\hline 1999 & 4471 & 10.8 & 68 & & 7450 \\
\hline 2000 & 4815 & 10.3 & 75 & 11 & 5114 \\
\hline 2001 & 4803 & 9.9 & 76 & 65 & 5150 \\
\hline 2002 & 4954 & 9.0 & 79 & 78 & 5299 \\
\hline 2003 & 5031 & 43.2 & 77 & 235 & 5774 \\
\hline 2004 & 0 & 49.2 & 82 & 199 & 6489 \\
\hline
\end{tabular}

\subsection{Green Building}

Green building is the practice of creating structures and using processes that are environmentally responsible and resource-efficient throughout a building's life-cycle from sitting to design, construction, operation, maintenance, renovation and deconstruction. The sustainable design would streamline the industry towards both environmentally and socially responsible solutions to the built environment

\subsection{Embassy of the Kingdom of Netherlands}

The new Embassy building has onsite renewable energy generation and utilization through photovoltaic panels and solar thermal panels for hot water; high spec glazing on both floors to enhance the building's energy performance. This is in addition to the use of energy efficient lighting and electrical equipment. The indoor environmental qualities were:

- Design and verification for thermal comfort conditions for all spaces.

- Automatic and occupant controllability of building systems, including lighting, temperature, humidity and airflow.

- $\quad$ Optimization of daylight as a design strategy for most of the building spaces.

- Low Volatile Organic Compounds (VOC) materials to be used in furniture and other indoor finishing products to reduce the effect of indoor contaminants.

\subsection{The Photovoltaic Panels}

The photovoltaic panels on the roof are used to generate approximately $7.2 \mathrm{~kW}$ of electrical power, which is used for offices lighting. Each panel produces up to $200 \mathrm{~W}$ and there are 36 panels covering an area of up to $52 \mathrm{~m} 2$. The panels are connected to 3 inverters that transform the $17 \mathrm{~V}$ DC to $230 \mathrm{~V}$ alternating current. The tilt angle is 35 degrees with south orientation. The used panels can be used in different applications such as: on-grid utility systems, on-grid commercial systems, and on-grid ground mounted systems. The panel provides more field power output through advanced cell texturing and isolation process, which improves low irradiance performance [7]. To get the optimum match between the solar generators' output power and the inverter's input power, an inverter type Sunny Boy 2500 has been used. 


\subsection{The Solar Thermal Panels}

The solar collectors are placed with the total collector surface amounts to $75 \mathrm{~m}^{2}$.The solar thermal panels are used in conjunction with the thermal storage system, which serves a number of purposes including increasing system generation capacity, efficiency and reliability with the possibility of integration with other functions such as water storage for fire application. The existing swimming pool is insulated with $70 \mathrm{~mm}$ insulation material which is covered with a reinforced watertight sheet.The solar collectors supply heat during the winter period. The heat is either directly transferred to the heating water network of the building or stored in the thermal storage [8]. The data for the panels used in the case study are summarizing as follows:

- Occupancy: 11 working hours in a day (07:00 am - 06:00 pm), 250 working days in a year.

- Heating Load: the peak heating load of the building is $58 \mathrm{~kW}$ in extreme winter (Dec., Jan. \& Feb.), 45 $\mathrm{kW}$ in winter (March) and $30 \mathrm{~kW}$ in intermediate season (April \& Nov.).

- Cooling Load: the peak cooling load is about $82.20 \mathrm{~kW}$.

As a result, the embassy building is less dependent on fossil fuels, the emission of greenhouse gasses will be reduced and less electricity will have to be withdrawn from the power company resulting in lower costs and energy savings.

\section{Methodology}

In this study, the available software for the analysis of renewable energy technologies has been used. It is used to perform energy production analysis for a proposed photovoltaic-grid connected power plant for the Netherland embassy project [9]. The RETScreen computer program consists of 6 steps procedure for evaluating the potential of the specific PV installation, which are setting site conditions, energy model, cost analysis, emission analysis, financial analysis and sensitivity and risk analysis. In the analysis of "energy model", the basic information of the site conditions; solar radiation, latitude of project location, annual average temperature, system characteristics, PV array technical information and power conditioning are loaded. This is in addition to the information on the local electric utility such as the demanded peak electrical load, and annual energy consumption demand in order to estimate the amount of energy coming from conventional sources that PV system will be able to replace. The energy model worksheet presents the proposed case system summary, fuel types, fuel consumption, capacity and energy delivered, based upon system characteristics and calculations in the Load and Network Design and Equipment Selection Worksheets [10] and [11]. The selected language is English; the currency in which the monetary data of the project is the Jordan Dinar; the units; Metric or Imperial units: Metric; the defined project location: Amman/King Abdullah; heating value: Lower heating value; and finally, the proposed project type: Power, Technology: Photovoltaic, and Grid type: Isolated-grid \& internal load). The two points to explain are:

1. The heating value, which is a measure of energy released when a fuel is completely burned. It is classified into; Higher Heating Value (HHV) and Lower Heating Value (LHV). HHV is calculated assuming that the combustion product is condensed and the steam is converted to water, while LHV is calculated assuming the combustion product stays in a vapor form [10]. The setting in this project is based on LHV.

2. The seven proposed project types [10] are: heating, power, cooling, combined heating and power, combined cooling and power, combined heating and cooling, and combined cooling, heating and power.

In this study, the setting used is for power only. In RETScreen software used in this work, the user entered the weather station location in the Solar Resource and System Load (SR\&SL) worksheet, which is copied automatically to the energy model worksheet. The model calculated the total annual solar radiation incident on the $\mathrm{PV}$ array (in $\mathrm{MWh} / \mathrm{m}^{2}$ ), and the annual average temperature (in ${ }^{\circ} \mathrm{C}$ ). Both measurements were calculated from monthly data entered by the user in the SR \& SL worksheet. The site reference details used in the project conducted herein. The user identified these data based on the offline database and online database connect-in RETScreen software (Table 2). 
Table 2.The site reference data used in the study

Latitude

Longitude

Elevation

Heating design temperature

Cooling design temperature

Earth temperature amplitude

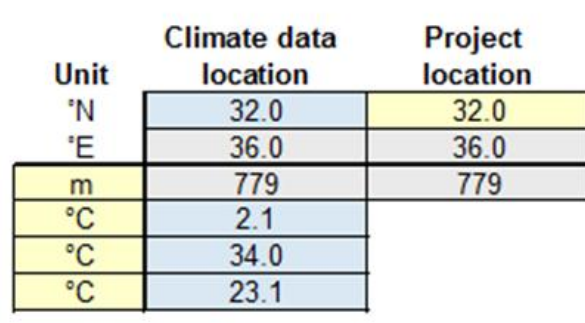

In addition to all above, the software needs to identify the months, air temperature $\left({ }^{\circ} \mathrm{C}\right)$, relative humidity $(\%)$, daily solar radiation $\left(\mathrm{kWh} / \mathrm{m}^{\wedge} 2 / \mathrm{d}\right)$, horizontal, atmospheric pressure $(\mathrm{kPa})$, wind speed $(\mathrm{m} / \mathrm{s})$, earth temperature $\left({ }^{\circ} \mathrm{C}\right)$, heating $\left({ }^{\circ} \mathrm{C} / \mathrm{d}\right)$, and cooling $\left({ }^{\circ} \mathrm{C} / \mathrm{d}\right)$. The data could be entered manually, if it's available, or it could be obtained from the software itself, since as mentioned above it is connected to NASA metrological data. These data are shown in Table 3.

Metrological data are function of time and elevation, therefore, these metrological indices are measured at constant elevation, and varied time. The study conducted in this work is based on power generation that is converting sunshine directly to electricity. The user also selects the type of grid from the two options in the drop-down list: "Central-grid" and "Isolated-grid". In this case the "PV energy absorption rate" should be specified [10]. The user has to define also the following: Power capacity; PV system manufacture; Model; Capacity factor; Electricity delivered to load; Electricity rate-base rate; and Electricity rate-proposed case.

Table 3.The Site data and weather parameters used in the study

\begin{tabular}{cllllllll}
\hline Months & AT* & RH* & DS* & AP* & W* $^{*}$ & ET* & H$^{*}$ & C $^{*}$ \\
\hline Jan & 7.7 & 74.80 & 2.7 & 92.9 & 3.2 & 11.7 & 319 & 0 \\
Feb. & 9 & 70.90 & 3.7 & 92.7 & 3.6 & 13.3 & 252 & 0 \\
March & 11.6 & 64.40 & 5 & 92.6 & 3.6 & 17.5 & 198 & 50 \\
April & 15.8 & 52.50 & 6.8 & 92.3 & 3.6 & 23.9 & 66 & 174 \\
May & 20 & 43.40 & 7.8 & 92.2 & 3.5 & 28.3 & 0 & 310 \\
June & 23.6 & 44.10 & 8.4 & 92 & 3.9 & 31.2 & 0 & 408 \\
July & 25.1 & 45.10 & 8.2 & 91.7 & 4.1 & 33.7 & 0 & 468 \\
Aug. & 25.2 & 50.80 & 7.5 & 91.8 & 3.6 & 33.8 & 0 & 471 \\
Sept. & 23.4 & 53.70 & 6.4 & 92.1 & 2.7 & 31.2 & 0 & 402 \\
Oct. & 19.9 & 57.50 & 4.8 & 92.5 & 2.3 & 25.5 & 0 & 307 \\
Nov. & 14.3 & 63.80 & 3.6 & 92.8 & 2.5 & 18.8 & 111 & 129 \\
Dec. & 9.4 & 72.90 & 2.7 & 92.9 & 2.9 & 13.3 & 267 & 0 \\
Annual & 17.1 & 57.80 & 5.64 & 92.4 & 3.3 & 23.6 & 1,213 & 2,719 \\
\hline
\end{tabular}

Where AT=Air Temperature $\left({ }^{\circ} \mathrm{C}\right)$, ET=Earth Temperature $\left({ }^{\circ} \mathrm{C}\right), \mathrm{RH}=$ Relative Humidity (\%), DSR=Daily Solar Radiation $\left(\mathrm{kWh} / \mathrm{m}^{2} / \mathrm{d}\right), \mathrm{AP}=$ Atmospheric Pressure $(\mathrm{kPa}), \mathrm{WS}=$ Wind Speed $(\mathrm{m} / \mathrm{s}), \mathrm{H}=$ Heating $\left({ }^{\circ} \mathrm{C}-\mathrm{d}\right)$, and $\mathrm{C}=$ Cooling $\left({ }^{\circ} \mathrm{C}-\mathrm{d}\right)$.

The above data are specifically defined for the proposed project. They were taken from two main sources, which are the Netherland embassy (the official owner of the project), while the rest variables such as electricity rate-base rate, and electricity rate-proposed case were taken from Electricity Regularity Commission [12].

The RETScreen energy model calculates the electricity delivered to load and the grid. In this project, no electricity will be delivered to grid, but only to load. Moreover, the user enters the electricity rate-base case in JOD/MWh. The government official department defined the electricity tariff to domestic sectors [13]. However, in Jordan there are two different electricity tariffs; these are: the average purchase price from generation sectors and the electricity tariffs to domestics sectors. The government claims that it pays about 550 Fils/kWh, while sell it to domestics by less than $50 \%$ of that cost.

In this study, the estimated of the electricity tariff to the Netherlands embassy is assumed to be 240 Jordanian Fils/kWh. This tariff is less than half of the average purchase price from generation sectors as 
the government claimed, as well as it is within the announcement tariffs of electricity rate for different domestic sectors regarding its consumption level. The estimated electricity equities consumed by the Netherland embassy in Jordan, based on monthly estimation are shown in Table (4).

Table 4. Monthly based estimation of electricity equities by the Netherland embassy in Jordan

\begin{tabular}{cccccc}
\hline Date & ND $^{*}$ & NDWH $^{*}$ & HS $^{*}$ & HH* $^{*}$ & HWH* $^{*}$ \\
\hline $03 / 2010$ & 31 & 22 & 5.6 & 1124.9 & 798.33 \\
$04 / 2010$ & 30 & 19 & 6.1 & 1185.84 & 751 \\
$05 / 2010$ & 31 & 20 & 6.5 & 1305.72 & 842.4 \\
$06 / 2010$ & 30 & 20 & 7.1 & 1380.24 & 920.16 \\
$07 / 2010$ & 31 & 21 & 7 & 1406.16 & 952.56 \\
$08 / 2010$ & 31 & 23 & 7 & 1406.16 & 1043.28 \\
$09 / 2010$ & 30 & 21 & 6.8 & 1321.92 & 925.34 \\
$10 / 2010$ & 31 & 21 & 5.8 & 1165.1 & 789.264 \\
$11 / 2010$ & 30 & 19 & 4.7 & 913.68 & 578.664 \\
$12 / 2010$ & 31 & 21 & 4 & 803.5 & 544.32 \\
$01 / 2011$ & 31 & 21 & 4 & 803.5 & 544.32 \\
$02 / 2011$ & 29 & 21 & 4.6 & 864.43 & 625.97 \\
Total & 366 & 249 & & 13681 & 9315.61 \\
\hline
\end{tabular}

Where ND=Number of Days, NDWH=Number of Days without Holiday, HS=Hours of Sunshine (angle 35), HH=Hours with Holiday, and HWH=Hours without Holiday

Source: Personal communication from employees in charge at the Netherlands embassy, Amman-Jordan.

\section{Results of the Energy Model Analysis}

The obtained results are shown in Tables (5), and (6).

Table 5.Base case power system Proposed case load characteristics of the study

(a) Base case power system

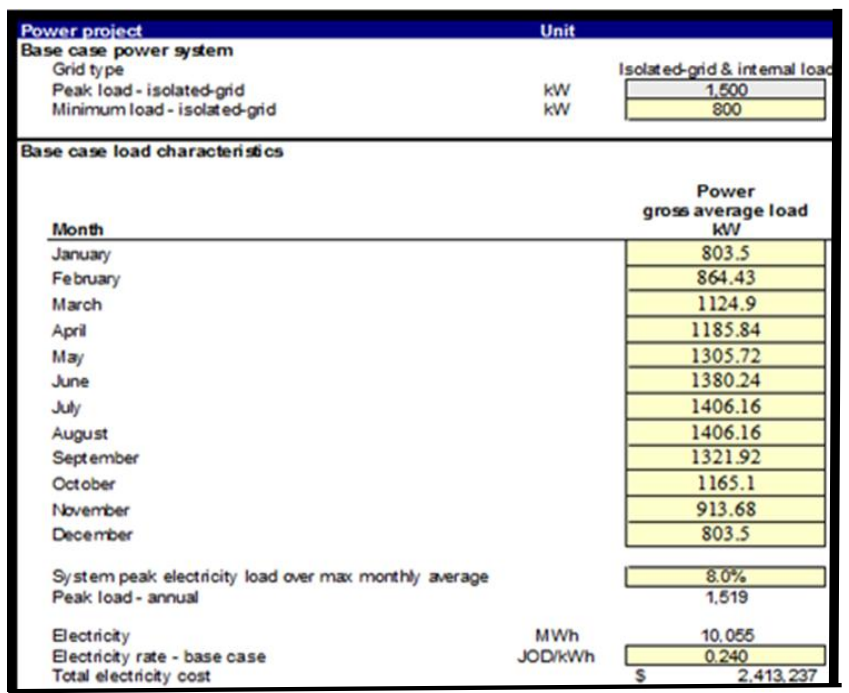

(b)Proposed case load characteristics

\begin{tabular}{|lc|}
\hline Proposed case load characteristics & $\begin{array}{c}\text { Power } \\
\text { net average } \\
\text { load } \\
\text { KWW }\end{array}$ \\
Month & 80 \\
\hline January & 26 \\
February & 112 \\
March & 119 \\
April & 131 \\
May & 138 \\
June & 141 \\
July & 141 \\
August & 132 \\
September & 117 \\
October & 91 \\
November & 80 \\
December & \\
& \\
Peak load - annual & 152 \\
\hline
\end{tabular}

The main input parameters identified to be feed into the first method (analysis technique) are: power capacity, manufacturer, model, capacity factor, electricity delivered to load, and electricity exported to grid (Table 6). Also, it need other parameters, those are: electricity rate - base case, fuel rate - proposed case power system, electricity export rate, and electricity rate - proposed case (Table 7). 
Table 7. Proposed case power system conducted of the study

\begin{tabular}{|c|c|c|c|c|c|c|}
\hline Proposed Case power syst & & & remental initial & & & \\
\hline Technology & & Photovo & & & & \\
\hline Analysis type & & Method 1 & & & & \\
\hline & ، & Method 2 & & & & \\
\hline Photovoltaic & & & & & & \\
\hline Power capacity & $\mathrm{kW}$ & 7.20 & $4.7 \%$ & & $14,331 \mathrm{JD}$ & \\
\hline Manufacturer & & Suntec & & & & \\
\hline Model & & y-Si - STP & -18 & 36 unit(s) & & \\
\hline Capacity factor & $\%$ & $1390.0 \%$ & & & & \\
\hline Electricity delivered to load & MWh & 833 & $82.8 \%$ & & & \\
\hline Electricity exported to grid & MWh & 0.0 & & & & \\
\hline Electricity rate - base case & $\mathrm{JOD} / \mathrm{MWh}$ & 240.00 & & $\mathrm{JOD} / \mathrm{kWh}$ & 0.240 & \\
\hline $\begin{array}{l}\text { Fuel rate - proposed case } \\
\text { power system }\end{array}$ & $\mathrm{JOD} / \mathrm{MWh}$ & 0.00 & & & & \\
\hline Electricity export rate & $\mathrm{JOD} / \mathrm{MWh}$ & 0.00 & & $\mathrm{JOD} / \mathrm{kWh}$ & 0.000 & \\
\hline $\begin{array}{l}\text { Electricity rate - proposed } \\
\text { case }\end{array}$ & $\mathrm{JOD} / \mathrm{MWh}$ & 0.00 & & $\mathrm{JOD} / \mathrm{kWh}$ & 0.000 & \\
\hline Operating strategy & $\begin{array}{r}\text { Elec. delive } \\
\mathrm{M} \\
\end{array}$ & ed to load & $\begin{array}{c}\text { Elec. exported } \\
\text { to grid } \\
\text { MWh }\end{array}$ & $\begin{array}{c}\text { Remaining elec. } \\
\text { required } \\
\text { MWh }\end{array}$ & $\begin{array}{c}\text { Power } \\
\text { system fuel } \\
\text { MWh } \\
\end{array}$ & $\begin{array}{c}\text { Operating } \\
\text { profit (loss) } \\
\text { JOD } \\
\end{array}$ \\
\hline Full power capacity output & 83 & & 44 & 173 & 0 & 241,334 \\
\hline Power load following & 83 & & 0 & 173 & 0 & 241,334 \\
\hline
\end{tabular}

The solar system delivered $833 \mathrm{MWh}$ of electricity to load while the total amount of required current is $1006 \mathrm{MWh}$. This is equivalent to $82 \%$ of the whole electricity needed.

Based on the data mentioned in Tables 6: The total cost of this system is 14331 JOD (\$20000); the annual energy saved is $9315.61 \mathrm{kWh}$; the estimated electricity tariff from the grid is $240 \mathrm{JDFils} / \mathrm{kWh}$; the annual cost saving is $9315.61 * 0.24=2236 \mathrm{JOD} /$ year; the payback period is $14330 / 2235=6.4$ year

\section{Discussion of Results}

The results of this study in comparisons with other previously published studies worldwide are discussed in the following sections:

\subsection{Geographical feasibility}

The electricity generation form PV panels relies on the quantity of solar radiation hits the photovoltaic panel. Thus, geographical feasibility of a location is most influential point [14]. The geographical location is determined by its; latitude, longitude, and elevation above the sea level. Based on the solar radiation in Jordan, $2080 \mathrm{kWh} / \mathrm{m} 2$, and its 300 sunny days yearly, it is concluded that Jordan has an excellent and promising potential power generation from solar energy, which basically constitutes a national promising resource that needs to be invested to the full extent [15].

\subsection{Environmental feasibility}

In fact, Jordan is one of developing countries that scour transparency in energy sector. Jordan sells its reduction of GHG to others developed countries such as Germany, which made it a national resource that returns direct cash flow to the Jordan treasury. As mentioned above the selling of GHG reduction to other developed countries has an effect on the real cost of electricity production and consequently on the prices given to the customers. On the other hand, it is proven by this study and other previously published studies worldwide, that the ability and effectiveness of renewable energy projects, including solar ones decrease the GHG emissions into a national and international scale.

\subsection{Economic feasibility}

Due to the country's dependence on subsidized and low cost natural gas imported from Egypt, 
Jordan's government had failed to initiate any meaningful progress in renewable energy and energy efficiency despite the obvious strategic importance in providing energy security and establishing the basis for economic development [16] and [17]. This has resulted in a shift to imported oil derivatives that have come at a much greater cost to the government. The cost of PV has come down dramatically in the last few years. In Jordan, PV has already attained grid parity today; i.e., it is well below today's cost of electricity of production of $\$ 0.25 / \mathrm{kWh}$, and below what some consumers pay (above $\$ 0.15 / \mathrm{kWh}$ ) [18] and [19].The results of the project cash flow are positive; the annual saving in electricity bill is more than the annual cost of the project. These findings support strongly the implementation of a local residential photovoltaic in Amman specifically, and in Jordan on a large scale.

\section{Conclusions}

Jordan is geographically suitable and promise to produce electricity from photovoltaic cell on a wide range scale. Due to high and escalating oil and natural gas price, and the decrease in photovoltaic technology cost, photovoltaic plans are economical reasonable solution to Jordan to produce electricity. This is in addition to the other important reasons as these cells are environmental friend and it decreases the GHG emission. It has been found in this study that, setting and running-on photovoltaic cell will reduce the electricity bill of the case study by 2236 JOD (\$3130) per year, with annual energy saving of $9315.61 \mathrm{kWh}$. This will annually eliminate $920.7 \mathrm{tCO}_{2}$ of GHG, and it inaugurated a good event, that may enhance others embassies, international, and national agencies to follow.

\section{References}

[1] Anoopa S. Energy and environment: A framework for action in the Arab region. Environment \& Energy Conference \& Exhibition, UNEP, 2003.

[2] Jeffery C, Raymond JK, Paul RP. Energy, Resources and Global Development. Science Magazine's State of the Planet 20062007, Washington, DC: American Association for the Advancement of Science, Island Press, 2006.

[3] Rehman S, Bader MA, Al-Moallem SA. Cost of solar energy generated using PV panels. Renewable and Sustainable Energy Reviews. 11: 1843-1857.

[4] Khammash T. CFA, CVA. (2012). The Jordanian Energy Sector, Jordinvest, Jordan Investment Trust P.L.C.

[5] Greenpeace International (2013). Jordan's Future Energy. Amman: Greenpeace International.

[6] Chedid R. Jordan Baseline Study, MED-ENEC Project, Energy Efficiency in the Construction Sector in the Mediterranean, Beirut, 2006.

[7] Nelson J. Solar Cells. Imperial College Press, 2003.

[8] The Netherlands Embassy in Amman Jordan (2011).

[9] Bakos GC, Soursos M. Technical feasibility and economic viability of a grid-connected PV installation for low cost electricity production. Energy and Buildings. 2002; 34: 753-758.

[10] MNR Ministry of Natural Resources. RETScreen Software Online User Manual. Minister of Natural Resources Canada, CANMET Energy Technology Centre. Varennes, Quebec, CANADA: Minister of Natural Resources Canada, 2005.

[11] Markovic D, Cvetkovic D, Masic B. Survey of software tools for energy efficiency in a community. Renewable and Sustainable Energy Reviews. 2011; 15: 4897-4903.

[12] Electricity Regularity Commission ERC. (2008). General Indicators for Economy and Energy.From Electricity Regularity Commission.

[13] Electricity Regularity Commission ERC. (2008a). Electricity Tariff.From Electricity Regularity Commission.

[14] USDEG United States Department of Energy (2013). Energy efficiency and renewable energy.

[15] Etier I, Al Tarabsheh A, Ababneh A. Analysis of solar radiation in Jordan. Jordan Journal of Mechanical and Industrial Engineering, 2010; 4(6): 733 - 738.

[16] Hoshberg M. Jordan's Energy Future: A Path Forward. Middle East Institute, 2015.

[17] JREF Jordan's Renewable Energy Future (2013).

[18] Fu R, Feldman D, Margolis R. US solar PV system cost benchmark. National Renewable Energy Laboratory. Technical Report NREL/TP-6A20-68925, 2017.

[19] Feldman D, Margolis R, James T, Weaver S, Dargouth N, Fu R, Davidson C, Booth S, Wiser R. PV system pricing trends. Sun Shot, US Dept. of Energy NREL/PR-6A20-62558, 2014. 